\title{
Enacting the Prevent Duty in Further Education
}

\author{
Natalie James
}

\begin{abstract}
This chapter explores staff and student experiences of the classroom implementation of the Prevent Duty within further education. It focuses on two key dimensions of the Duty: the teaching of Prevent and its role as a safeguarding mechanism. It highlights the malleable nature of the Duty, whereby educators have tailored their enactment of it in ways that they believe can help overcome some of the problems the Duty was perceived to have raised. It also highlights however that the ability of staff and students to enact the Duty in this way was constrained by the processes of governance which surround the Duty and the dominant public narratives of prejudice which inform and are informed by it.
\end{abstract}

Keywords Prevent Duty $\bullet$ Further education $\bullet$ Malleability $\bullet$ British values $\bullet$ Safeguarding $\bullet$ Students $\bullet$ Staff agency

N. James $(\bowtie)$

School of Politics and International Studies, University of Leeds, Leeds, UK e-mail: ptnj@leeds.ac.uk 


\section{Chapter Summary}

Annual Prevent statistics have continuously placed the education sector as the leading area from which Prevent referrals emerge. Moreover, the age range most likely to be referred has consistently been the 15-20 category since the Duty's inception (see Chap. 1). This would suggest that the further education (FE) sector has been under an enormous pressure to comply with the Prevent Duty, yet there has been little research undertaken regarding the only education sector dealing with predominantly 16-18-year-olds (see Beighton \& Revell, 2018; Moffat \& Gerard, 2020). This chapter presents an insight into some of the key findings which emerged from a three-year study into experiences of the Prevent Duty within Greater Manchester's (GM) FE sector.

Focusing on the practicalities of implementation within the classroom, this chapter explores how FE teaching staff sought to embed the Prevent Duty within their institutions. It does so by revealing two dominant spaces through which staff translated the legislation into practice: through their teaching practices and their institutional safeguarding processes. Moreover, it also highlights the role students played at these sites of implementation, exploring the extent of both their involvement in and their acceptance of such measures.

Like other chapters in this volume, this chapter also utilises Ball, Maguire, and Braun's (2012; see also Braun, Ball, Maguire, \& Hoskins, 2011) concept of enactment and consideration of context to explore how the implementation of the Duty by staff and their students within the classrooms of FE institutions occurred and the limitations which surrounded their approaches. In doing so, this chapter argues that such experiences highlighted a malleable nature to the Prevent Duty, whereby educators were able to tailor their enactments to the needs of their institution and those within it. Moreover, in viewing the Duty as malleable, this enabled educators to use their implementation to overcome some of the perceived problems which Chap. 2 of this volume explores. Yet, in revealing these sites where the Duty could be interpreted through the eyes of educators, this chapter also highlights the contextual factors which limited them, such as the processes of governance which surround the Duty and the dominant public narratives of prejudice which inform and are informed by it. 


\section{The FE Context}

Critical to reading the following findings is an understanding of the context in which these actions were taken. The year 2015 was momentous for the FE sector. Not only did it face the introduction of the Prevent Duty, but the school-leaving age was also increased from sixteen to eighteen. Therefore, from 2015, anyone up to the age of eighteen was required to be in either education or training, and thus subject to the Prevent Duty - a key part of this then became the management of adult learners who were still subject to the same safeguarding procedures as children within secondary or primary schools. For the FE sector, this meant not only an increased demand for services but also an increased demand on staff to deliver a variety of curriculums to a diverse student body. It also created a new space within which staff simultaneously had the responsibility to protect students from extremism and terrorism under their safeguarding responsibilities, whilst also transferring this responsibility of protection over to students in their passage from childhood to adulthood. This was further complicated by the inclusion of mature students within this realm, blurring the boundaries further of where responsibility lay for preventing oneself and those around them from becoming vulnerable to radicalisation (James, forthcoming). Moreover, it also brought training providers, often in the form of private companies, squarely into the mix for being subject to the same inspections and regulations that academic providers were, through their inclusion to the FE sector.

\section{Research Basis}

This chapter draws on a three-year study engaged with both staff (13 participants) and students (45) across five institutions within Greater Manchester (GM), which comprised two training and three academic providers. Representatives from local councils, the Department for Education, independent training providers, the North West CounterTerrorism Unit and Ofsted also participated. The study was undertaken through focus groups (9), semi-structured interviews (21), participant 
observation (9) and an online questionnaire (49). Respondents have been anonymised in the extracts that follow and participants in the student focus groups selected their own pseudonyms (see James [forthcoming] for further methodological detail). Although seven of the ten GM boroughs were included in the research, such small-scale research cannot claim to produce generalisable results about the whole of the FE sector, or even FE provision in GM. Rather the research generates insights into processes of policy enactment in FE institutions, and in doing so helps to illustrate how the Prevent Duty comes to have impacts on staff and students.

The Manchester Arena bombing in 2017 also occurred as access for fieldwork was being negotiated (fieldwork was undertaken between October 2017 and November 2018). Whilst there is no available measurement of the impact this had on the data, it is likely that this event had a bearing on some of the experiences obtained. Indeed, it was referenced by several participants - both staff and students - as bringing these issues to the forefront of their minds when implementing Prevent.

\section{Teaching Prevent}

For the vast majority of teaching staff who took part in this research, their training on Prevent had been delivered to them by their designated safeguarding lead (DSL). The session was an adapted version of the government's Workshop to Raise Awareness of Prevent (WRAP) training, which enabled a tailored approach from the generic public sector training into one suitable for their particular institution. Respondents involved in the delivery of such training indicated that this had been the general approach to training for some time and highlighted the malleability in the Duty to go through such adaptations. Though the nature and content of the training varied, this institutional level of training was designed to enable teaching staff to gain the knowledge and access to resources necessary to embed the Prevent Duty into their classroom. Teaching staff would then further adapt this training for their own pedagogical needs. Thus, prior to the Duty being enacted within the classroom, there already existed two 
sites of transformation within the institutions through which the Prevent Duty became implemented: at DSL level and at teaching staff level.

It is the second process with which this chapter is concerned. For teaching staff, the Prevent Duty meant ensuring students were resilient to the ideologies of extremism and terrorism through two key means-via pedagogical practices around what extremism and terrorism might look like, and promoting fundamental British values within the classroom, the latter of which I deal with first. The experiences highlight the ways in which educators were able to tailor their enactments within the classroom as a result of the Duty's malleability, but also how the governance processes surrounding this, and in particular inspection regimes, placed constraints on this malleability.

\section{Teaching Fundamental British Values}

British values are defined by the UK government as democracy, individual liberty, the rule of law, and mutual respect and tolerance of those with different faiths and beliefs (Department for Education, 2014). Though, as an agenda, they have been within political discourse since the premiership of Gordon Brown, they became cemented in the education system through the Prevent Duty in their presentation as the antithesis to the values of extremist and terrorist ideologies (James, 2018). Here, embodying British values was presented as a means of resilience against becoming radicalised (McGhee \& Zhang, 2017). Thus, teaching staff were tasked with the responsibility of ensuring that British values were embedded within their classroom delivery: the education system acting as a site of citizenship development (see Jerome \& Clemitshaw, 2012). For many of the teaching staff who participated, encouraging good citizenry was nothing new, nor was the utilisation of a values agenda in the promotion of this. The provision of Spiritual, Moral, Social and Cultural (SMSC) development within pedagogic practices was, for them, a longstanding values agenda that was already central to their classroom delivery. Thus, it was not the idea of a values agenda, nor the values themselves, which were perceived as problematic, as both were seen as a continuation of the existing SMSC agenda. Rather, it was the labelling of these values as distinctly 'British' which created a number of potential issues. 
A number of the participants raised concerns around the extent to which 'British values' could encompass all students, particularly those who did not perceive themselves as being British or of a primarily British identity. Both teaching staff and students questioned the usefulness in labelling the values as 'British' when, for them, they were 'human' or 'universal' values and thus applicable to people outside of Britain too. For many there was nothing distinctly British about the values; rather, they were values to which anyone could adhere; though some conceded this was anyone within the West, noting the Western-centric narratives at the heart of the values themselves (Winter \& Mills, 2020; Miah, 2017; Revell \& Bryan, 2018). Some respondents viewed the British label as problematic as it was perceived to place Britain, and those easily identifiable as 'British', as being superior to Others. These sentiments were particularly strong amongst some of the students, with this excerpt reflecting a number of the fieldwork conversations that took place:

Isla: They should be everybody's values

Rachael: Yeah

Lois: $\quad$ Yeah it just segregates so many people, it's like

Interviewer: In what way, do you think?

Lois:

Because, if you're a good person, [Isla: it doesn't matter what country you're from] it doesn't matter where you're from, what religion you've got, what race, you know it's just like you don't have to have an excuse to be a nice person and it doesn't matter if you're living in Britain and you don't consider yourself British, it's like, you know, it feels like it could isolate some people being like 'you have to, you know if you're going to be a nice person you have to British!' it's like well you don't! (Academic Institute 1, Female Focus group)

For these students, and for a number of their peers who participated in the research, the fundamental British values agenda was interpreted through this lens of hierarchical goodness (who could be a good citizen or not) and gave rise to concerns around the potential exclusion which could occur as a result of the Us versus Them narrative they perceived this British label to have (Smith, 2016). 
Many staff and student participants expressed fears that in defining the values as British, the agenda would further exclude or alienate those students who did not identify as British, who were often more visible by their ethnic, cultural, religious or linguistic identity anyway, further emphasising their difference. As one teacher noted:

They're British values, but they're everyday values, they're all about respect and tolerance, treating people how you want to be treated, and a lot of our clientele, ninety percent are non-British, or don't identify as being British, so we go through British values, and they're like 'well I'm not British, do they not apply to me?' (Counselling, Psychology and Mental Health Educator, Training Institute 2)

This also raised concern about those who had such visible markers of difference whilst also considering themselves as British. For both staff and student participants, there was a grey area in how these students would manage their multiple identity structures. For a number of staff and student participants, markers of difference became, or had the potential to become, hyper-visible. Many of the staff participants who raised concerns around this suggested that whilst students knew they were 'British values', staff instead referred to the values as 'human', 'our', 'college' or 'universal' values to both minimise these fears and the potential for those who did not identify as British from being excluded from the notion of good citizenship in an attempt to actively include them within discussions around this (see Busher, Choudhury, Thomas, \& Harris, 2017).

It is important to note that there were, however, some respondents who did not express concerns around British values. For some, British values were viewed as unproblematic.

I think the British values stuff is just like the basics of what makes our society work erm and what creates sort of like cohesion within us all. (Politics Educator, Academic Institute 1)

Moreover, for some, 'British values' were not only something that were felt to be central to upholding the way of life in Britain, they should also be celebrated. 
I fully appreciate British values, I totally understand democracy, the rule of law, I can see the difference between what happens in the UK and what happens in my country, for example, I'm from South America. (Social Care Educator, Training Institute 2)

Thus, for some of the respondents, British values were a positive addition to the education sector which gave the opportunity for a 'multiplicity of voices' to be united (Politics Educator, Academic Institute 1) both inside and outside of the classroom.

Nonetheless, even amongst those who advocated for the language of Britishness, there remained an overwhelming sense that the labelling of the values as British had not been because they could only be seen through such a framework, but because this had become a directive from Ofsted through the common inspection framework. In this sense, the performativity of their enactments as noted in Chaps. 5 and 7 of this volume are also visible in the further education sector:

I think we do British values every lesson regardless of whether we were told to do British values or not you know what I mean? [...] so you know it's just about signposting it you know [...] but we've got a poster on the wall about it [...] cos obviously when British values came in, we had to evidence to Ofsted that you know it's within our classrooms at all times [...] it would be about the signposting around the college and if Ofsted popped into your lesson, to mention the word British values and that should tick the boxes. (Politics Educator, Academic Institute 1)

Though this Politics educator had not problematised the British framing of the values agenda, evident in an earlier excerpt, she simultaneously labelled its integration into the classroom as an exercise to 'tick the boxes' for Ofsted. Embedding British values then became about staff performing their duty (Ball, 2003). This performativity, however, was more problematic in the classroom for some. For example, another educator who did not reject the fundamental British values label altogether, nonetheless, suggested that Ofsted's requirement for the British label to be visible within their enactments of the Duty had made teaching these values more onerous. She suggested that without extra time and effort taken to explore the relevance and necessity of the agenda, and its position within British society, the label of the values as British created a barrier for 
students to meaningfully engage: 'they'd be like "ugh, British values, ugh" and look at you' (Business Access to HE Educator, Training Institute 2). For this educator, the agenda itself was not problematic, but its governance was. In Ofsted's requirement for it to be explicitly referred to as a fundamental British values agenda, her ability to tailor her enactment of the Duty became limited. Where the agenda was labelled as just values, there were fewer issues which arose from students, she suggested, but where the framing of it as British became required for Ofsted inspections, the rejection or reluctance visible in students (see also above) resulted in her having to deconstruct its value and worth within her classroom. Thus, her ability to utilise the malleability of the Duty became limited once the perceived requirements of Ofsted governed her enactment of it within the classroom.

Whilst the extent to which staff accepted the values being labelled British varied, this performative nature of British values, as a result of Ofsted's requirement, remained constant throughout their experiences. This limitation arose out of staff members concerns that a failure to make these visible would result in a potential sanction for them and their institution. The pressure to perform during inspections and the stakes for not doing so acted as a deterrent to completely omit the language from the classroom. Though Andrew Cooke, North West Head of Ofsted, stated there was no requirement to see British values referred to explicitly, the following admission suggested that its absence would be flagged as something which required investigation:

If it wasn't called British values then, I don't think you know, well we would ask perhaps why, I suppose sometimes the question is if people deliberately don't use the word British, you then ask the question why, and what's driving that?

The experiences highlight the nuances, or grey areas, which surrounded the implementation of the fundamental British values agenda. Moreover, these perceptions of the common inspection framework and its requirements of staff also reveal the ways in which the Duty intersected with wider systems of governance and the pressure which staff, in particular, felt as a result. 


\section{Teaching About Extremism and Terrorism}

A second area in which Prevent shaped pedagogical practice was in staff provision of the knowledge around what extremism and terrorism might look like. Some participant staff suggested that this was embedded within their day-to-day curriculum, through the encouragement of critical thinking skills but almost all placed the primary focus in teaching Prevent on specific sessions which sought to educate students around the signs and risks of radicalisation. For most, this came in the form of tutorial sessions in which broader citizenship agendas were delivered, with one or two weeks per year dedicated specifically to Prevent. These were labelled 'raising awareness' sessions which were about 'building learner resilience' (Teacher Trainer, Training Institute) through providing them with the knowledge and skills to identify and subsequently reject extremist or terrorist narratives. Sessions provided examples, which I shortly discuss, of the processes of radicalisation and students being asked to explore what signs were shown, how these could have been stopped, and informed of what support might be put in place. These sessions were supplemented by posters which were visible in each room in each institution participating in the research that stated who to speak to should a student, or staff member, be concerned that they or someone they know is or might be being radicalised. As with the perceived expectations around the regulation of British values, teaching staff also perceived their engagement with Prevent in the classroom to be inspected and thus requiring evidencing. Sessions solely devoted to this gave them a clear-cut means of doing so. For a number of staff members, external resources provided an avenue for them to obtain the evidence they perceived necessary to pass an inspection:

[The students] have to do a test at the end [of the workshop] and they get a certificate which they send to me (...) it's one more thing that I can say if Ofsted come and go "how does X, Y, and Z know that" it's just one more thing to back me up. (Business Administration and Customer Service Educator, Training Institute 2)

The emphasis this educator placed on being able to provide evidence for Ofsted was replicated by the majority of teaching staff who participated. 
I suggest this was largely due to the context of compliance and regulation within which the Prevent Duty was placed and which was already shaped through these modes of governance (Ball et al., 2012). Yet, despite their familiarity with the requirements to evidence their compliance, this was still viewed by many of the staff members to be a limit upon their enactments, because of the power that Ofsted was perceived to exert through their requirements to pass inspections. Whilst many of the DSLs voiced a preference for Prevent being brought in through 'naturally' occurring conversations, many of the teaching staff did not feel this to be enough to demonstrate their teaching of Prevent. As a result, whilst staff adopted their own approach to the pedagogy of Prevent, their scope for interpretation was constrained by the perceived need to utilise approaches which would provide tangible evidence that they could have on 'standby' should they be asked for it by Ofsted.

The utilisation of external resources to conduct these sessions was commonplace across the institutions, whether in the form of videos, infographics, online sessions or a combination. A number of these educators, and in some cases their DSLs, would seek out a variety of external resources to create packages of learning in order to direct and aid their delivery of content which was largely unfamiliar to them. The capacity to use external resources allowed staff to bridge knowledge and confidence gaps, enabling them to distance themselves from the content and instead provide pedagogic support around the skills that would require students to navigate the knowledge that had been supplied from elsewhere.

Moreover, most staff utilised these external sources in their attempts to avoid presenting simplistic or one-sided accounts of radicalisation by carefully selecting or developing their own resources. For these staff members, there remained an over-emphasis on Islamist-related concerns within the materials which were provided as learning resources. As a result, a number of staff who participated saw many of the generic resources associating radicalisation with Islam and thus Muslim students being seen as the target of the agenda (also see Dudenhoefer, 2018; Kyriacou, Szczepek Reed, Said, \& Davies, 2017; Saeed, 2017). Though many of the DSLs had sought to provide resources that did not propagate such stereotypes, a number of teaching staff felt such adaptions had not gone far enough and therefore sought to further minimise the risk of 
stigmatising Muslim students by supplementing these resources with their own. This commonly included the use of what staff referred to as examples of different forms of extremism, with focus predominantly placed on far-right inspired extremism as well as Islamist examples. Staff saw these efforts as their attempts to move Prevent away from being focused primarily on Muslims (see Chap. 2). Whilst several of the staff observed that it was problematic that these adaptions were necessary, their ability to enact the Duty through their own resources highlighted the malleability of the Duty and thus the capacity of those on the ground to shape it.

A significant proportion of the staff suggested, however, that the dominance of wider public narratives of prejudice which placed Islam as a security threat limited the effectiveness of their efforts to shift perceptions about the focus of the Prevent Duty. These narratives were seen as constraining such efforts in two ways. Firstly, some staff recognised that ongoing exposure to prejudicial depictions of Islam within the media and government rhetoric was likely to give rise to bias within their own thinking and professional judgement. Secondly, some staff at least expressed the view that within a context of entrenched public discourses that positioned Islam as the primary terrorist threat, their attempts to challenge these depictions were likely to have limited effect.

Students recognised the attempts by staff to bring in non-Islamist forms of extremism and terrorism to their sessions, but also referenced the same problematic narratives of prejudice which conceptualised Islam, and therefore Muslims, as the terrorist threat. Almost all of the students who participated believed that it was the media who created this narrative of the terrorist as 'the Asian guy with the beard' (Rio, Student, Mixed Focus Group, Training Institute 2):

Like any brown person that you see on the street, they get labelled instantly don't they. (Henry, Student, Mixed Focus Group, Academic Institute 2)

This sentiment was echoed by a number of students who suggested that white perpetrators of violence were often depicted, in contrast, as mentally unstable. Therefore, for many of the students, racial, cultural and religious signifiers had become central markers for understanding who 
could be seen as threatening and thus the target of programmes like the Prevent Duty_namely Muslims, and those who looked Muslim. Efforts by their teachers to challenge this were welcomed but not perceived as enough to break such narratives down.

Many of the staff participants similarly recognised the barrage of media images and rhetoric that had been in place since $9 / 11$ and had played an important role in shaping these young people's perceptions of terrorism (See also Jerome \& Elwick, 2019). For the majority of their students, Islamist-inspired terrorism had been all they had ever known. Moreover, for a number of staff and students, there was a feeling that by the point of further education, attempts to break down these perceptions were too little too late for individuals for whom these narratives had been accepted and normalised. For these staff members, their students pre-learned perceptions meant their job to break down these narratives became even more challenging at an age where their views were already formed as they were entering into adulthood. As a result, for staff members, their efforts to minimise the problematic conceptions surrounding threat(s), and thus Prevent, rested not only on their capacities to shift away from a simplistic and one-sided presentation of radicalisation in their resources but also on their abilities to break down entrenched perceptions of who was likely to become radicalised. Thus whilst the Duty provided the space for other forms of extremism to be explored, and for previous claims around its targeting to be minimised, staff enactments to fulfil these adaptations through ground-level implementation were limited by such deeply engrained narratives of prejudice within the wider public discourse.

\section{The 'Safeguarding' Dimension of Prevent}

Existing scholarship indicates broad acceptance within the education sector of the framing of Prevent as a safeguarding mechanism (Bryan, 2017; Busher, Choudhury, \& Thomas, 2019; Jerome, Elwick, \& Kazim, 2019). This was also found among the staff who participated in this research. Many did see the introduction of the Prevent Duty as an extension of their existing responsibilities around safeguarding their students from potential harms, with radicalisation seen in the same vein as child sexual 
exploitation, abuse or substance misuse. Although some respondents made reference to the Counter-Terrorism Unit becoming involved in discussions around referrals for DSLs, once external support was felt to be required (James, forthcoming), internal referral processes relating to concerns over potential radicalisation issues followed normal safeguarding procedures for teaching staff.

Where concerns were raised, teaching staff would disclose the matter to safeguarding teams, whether through a paperwork trail or an online system, and their DSL would then investigate the concern. In this sense, referrals under the Prevent Duty were no different than any other form of safeguarding. Whilst many online participants described this referral process, face-to-face participants revealed a further layer of deliberation. This comprised informal conversations with colleagues prior to informing their safeguarding teams to gain further reassurance that their concerns were valid. Of note, respondents described these conversations as being more likely to take place in cases related to radicalisation than other forms of harm. Such discussions, often outside of the safeguarding team, were described as providing staff themselves with a safeguard against making the wrong call. This, in many cases, related to when staff had a gut feeling but wanted to affirm this with others. As one member of staff noted, this was partly a result of trying to manage their own possible unconscious bias. As she explained, when concerned about a Muslim student, she used these informal conversations with colleagues as a means of reducing the risk that she was over-interpreting the situation because of her religion:

I talked to other members of staff who said, 'no, refer it', so that was nice: that we could discuss it without kind of breaking data protection or anything like that, I could discuss it with other people and that reassured me that I could report it. (Fine Art Educator, Academic Institute 1)

For this staff member, it was the fear of 'interfering with that student's right to be religious' by viewing her increased religiosity as a central reason for referral which led them to seek reassurance from colleagues that it was not their bias which was guiding their referral but a shift in behaviour. Student discussions also noted concerns around potential unconscious bias from staff members in their referrals: 
I'm not saying I'm a terrorist (laughs) but I might show the same traits or warning signs or something but as like a small white girl I don't think it'd be picked up as like 'she might be a terrorist' like I don't think I'd have that problem whereas say, this college is very diverse, and I think if some other, like if a lad was like that and he was from a different ethnicity, from a different background, I think he would be more likely to be picked out as 'ooh what's this about' rather than, like me. (Ava, Student, Academic Institute 1)

This extract from Ava's dialogue demonstrates the perception visible within a number of students' experiences, that a perceived Muslimness was central to whether or not someone could be viewed as being potentially radicalised. Cultural, ethnic and religious markers of difference were seen by students who shared Ava's concerns as markers of 'risk' (Heath-Kelly, 2013) which became hyper-visible in their perceived association with terrorism. For a number of students, fellow students with these 'traits' were perceived to therefore be hyper-visible to those deciding who was 'at risk' of radicalisation. Yet, despite their reservations, almost all of the students thought that those deemed 'at risk' of radicalisation should be referred to the relevant authorities.

The notion of better to be safe than sorry was evident in many of the experiences - of both staff and students-where the potential fallout from a wrong call was seen to be a far lesser burden to carry than that of missing an opportunity to stop an attack(er). As in McGlynn and McDaid's (2018) study of university students' perceptions of Prevent then, the student participants in this study also appeared to accept and to have internalised the idea that Prevent comprised a legitimate form of safeguarding:

It's safeguarding isn't it? [...] you're [as a teacher] in place of the parents [...] so if you suspect somebody you're not only protecting them like trying to get them out of that scenario, you're protecting everybody else involved because if something was to happen, it's not just them being affected, it's the entire community. (Ashleigh, Student, Mixed Focus Group One, Training Institute 1) 
Though students understood they were being asked to be aware of the signs of radicalisation, the vast majority suggested that this was not something they felt was required of them, nor would it be something they would anticipate ever having to do. For most of the students in the research, though the threat of radicalisation was real, it was not something that was familiar or close to them or their peers. It was only after an attack had happened that students felt their awareness around terrorism and extremism became heightened; outside of these, this was something that felt distant. For students who suggested that the Manchester Arena attack did bring concerns around terrorism to their attention, their focus was placed on those impacted by the events, rather than the perpetrator. The likelihood that they or those they knew would be impacted by a terrorist attack, even after the arena bombing, was low, but the likelihood that they or their friends might be the ones to perpetrate such an act was even lower. Instead, students' concern over their friends would be put down to mental health, family problems, stress or other well-being issues; putting a concern down to potential radicalisation would be 'a last resort' (Rachel, Student, Mixed Focus Group, Academic Institute 1). For students in the research, the visibility of attacks reified the presence of threat within wider society, but the perception that this was something they or their friends might be involved with was distanced.

These experiences highlighted an internalisation of the Prevent Duty as a safeguarding mechanism. For both staff and students, the Duty's enactment through those existing platforms of safeguarding was simply a continuation of the practices and principles of their institutions to protect students from harm. The concerns felt by some were largely seen as not being a result of the Duty itself, but as resulting from the problematic narratives of prejudice which surrounded perceptions of who the Duty was most likely to be preventing.

\section{Conclusion}

Through this exploration of staff and student experiences, two narratives have emerged which, together, enable us to tell this story of the implementation of the Prevent Duty within these further education institutes. 
Firstly, the experiences highlighted the way in which the malleability of the Duty enabled staff to utilise existing practices and processes as a means of embedding the Duty into their current pedagogical practices. Whether through its embedding of a values agenda or its requirement to refer those vulnerable to radicalisation, the Prevent Duty became something which was accepted and integrated into existing mechanisms. In this sense, the Duty simply extended responsibilities and actions that had already been expected of staff.

Secondly, there is a story of the limitations surrounding these enactments. The limitations emerged from two key places: the processes of governance which regulate the Duty, and the wider public narratives of prejudice which inform and are informed by it. The malleability of the Duty enabled staff to minimise the perceived stigmatisations and divisions which were felt to inform Prevent as a counter-terrorism agenda. This occurred through a shift away from an isolated focus on Islamistinspired terrorism, a distancing from values as distinctly British and a recognition of internal bias regarding potential referrers. For educators and their students, these actions enabled them to challenge and seek to minimise the potential negative effects of the Prevent Duty that they perceived. However, staff members often perceived that their attempts to shift the focus of the Duty away from Muslims, or those who looked Muslim, were ultimately rendered fairly ineffective by the power of the public discourse which continued to perpetuate the idea that Prevent work did and ought to focus on Muslims.

The second place in which these limitations became apparent was in the processes of governance which surrounded the Duty. Staff perceived the Duty's malleability to be limited by the requirements of Ofsted. Whilst external resources helped teachers bridge knowledge and confidence gaps, they were also used to obtain documented evidence of teaching Prevent; whilst 'Our' values were advocated, 'British' values were on posters or dropped in during inspections to ensure compliance. For many of the staff then, the Duty's malleability opened up possibilities for varied enactments, but only so long as they could provide evidence of meeting the expectations of Ofsted.

It seems then that in FE, as in other parts of the education sector (Chaps. 5, 6, and 7), staff made use of significant malleability within the 
Prevent Duty to enact it in ways that they saw as fitting with their wider professional practice and commitment to the education and well-being of their students, and that arguably challenge some of the popular critiques of the Prevent agenda. Yet at the same time, the scope of educators and their students to interpret the Prevent Duty as they wanted was constrained by the environment in which they were operating, both in terms of the wider public discourses inscribed with significant and persistent anti-Muslim prejudice, and in terms of the processes of governance that often undermined the willingness or confidence of educators to exercise their professional judgement.

\section{References}

Ball, S. J. (2003). The teacher's soul and the terrors of performativity. Journal of Education Policy, 18(2), 215-228.

Ball, S. J., Maguire, M., \& Braun, A. (2012). How schools do policy: Policy enactments in secondary schools. London: Routledge.

Beighton, C., \& Revell, L. (2018). Implementing the " in England: the semiotisation of discourse and practice in further education. Discourse: Studies in the Cultural Politics of Education, 1-16.

Braun, A., Ball, S. J., Maguire, M., \& Hoskins, K. (2011). Taking context seriously: Towards explaining policy enactments in the secondary school. Discourse: Studies in the Cultural Politics of Education, 32(4), 585-596.

Bryan, H. (2017). Developing the political citizen: How teachers are navigating the statutory demands of the counter-terrorism and security act 2015 and the Prevent duty. Education, Citizenship and Social Justice. https://doi. org/10.1177/1746197917717841.

Busher, J., Choudhury, T., \& Thomas, P. (2019). The enactment of the counterterrorism "Prevent duty" in British schools and colleges: Beyond reluctant accommodation or straightforward policy acceptance. Critical Studies on Terrorism, 12(3), 440-462.

Busher, J., Choudhury, T., Thomas, P., \& Harris, G. (2017). What the Prevent duty means for schools and colleges in England: An analysis of educationalists' experiences. Retrieved from http://eprints.hud.ac.uk/id/eprint/32349/ 
Department for Education. (2014). Promoting fundamental British values through SMSC. Retrieved from www.gov.uk/government/publications/ promoting-fundamental-british-values-through-smsc

Dudenhoefer, A. L. (2018). Resisting radicalisation: A critical analysis of the UK Prevent duty. Journal for Deradicalization, 14, 153-191. Retrieved from http://journals.sfu.ca/jd/index.php/jd/article/view/138

Heath-Kelly, C. (2013). Counter-terrorism and the counterfactual: Producing the 'radicalisation' discourse and the UK PREVENT strategy. The British Journal of Politics and International Relations, 15(3), 394-415.

James, N. (2018). Mapping the malleability of British values. Centre for analysis of the radical right. Retrieved from www.radicalrightanalysis. com/2018/09/20/mapping-the-malleability-of-british-values/

James, N. (forthcoming). An intersectional feminist analysis of experience of the Prevent duty in further education. Unpublished doctoral dissertation, University of Leeds.

Jerome, L., \& Clemitshaw, G. (2012). Teaching (about) Britishness? An investigation into trainee teachers' understanding of Britishness in relation to citizenship and the discourse of civic nationalism. The Curriculum Journal, 23(1), 19-41.

Jerome, L., \& Elwick, A. (2019). Identifying an Educational Response to the Prevent Policy: Student Perspectives on Learning about Terrorism, Extremism and Radicalisation. British Journal of Educational Studies, 67(1), 97-114.

Jerome, L., Elwick, A., \& Kazim, R. (2019). The impact of the Prevent duty on schools: A review of the evidence. British Educational Research Journal. https://doi.org/10.1002/berj.3527.

Kyriacou, C., Szczepek Reed, B., Said, F., \& Davies, I. (2017). British Muslim university students' perceptions of Prevent and its impact on their sense of identity. Education, Citizenship and Social Justice, 12(2), 97-110.

McGhee, D., \& Zhang, S. (2017). Nurturing resilient future citizens through value consistency vs. the retreat from multiculturalism and securitisation in the promotion of British values in schools in the UK. Citizenship Studies, 21(8), 937-950.

McGlynn, C., \& McDaid, S. (2018). Radicalisation and counter-radicalisation in higher education. Bingley, UK: Emerald publishing.

Miah, S. (2017). Muslims, schooling and security: Trojan horse, prevent and racial politics. Chams, Switzerland: Palgrave Macmillan. 
Moffat, A., \& Gerard, F. J. (2020). Securitising education: an exploration of teachers' attitudes and experiences regarding the implementation of the Prevent duty in sixth form colleges. Critical Studies on Terrorism, 13(2), 197-217.

Revell, L., \& Bryan, H. (2018). Fundamental British values in education: Radicalisation, national identity and Britishness. Bingley, UK: Emerald Publishing.

Saeed, T. (2017). Muslim narratives of schooling in Britain: From 'Paki' to the 'would-be terrorist'. In Máirtín Mac an Ghaill \& C. Haywood (Eds.), Muslim students, education and neoliberalism: Schooling a 'suspect community' (pp. 217-231). London: Palgrave Macmillan.

Smith, H. J. (2016). Britishness as racist nativism: a case of the unnamed 'other'. Journal of Education for Teaching, 42(3), 298-313.

Winter, C., \& Mills, C. (2020). The Psy-Security-Curriculum ensemble: British Values curriculum policy in English schools. Journal of Education Policy, 35(1), 46-67.

Open Access This chapter is licensed under the terms of the Creative Commons Attribution 4.0 International License (http://creativecommons.org/licenses/ by/4.0/), which permits use, sharing, adaptation, distribution and reproduction in any medium or format, as long as you give appropriate credit to the original author(s) and the source, provide a link to the Creative Commons licence and indicate if changes were made.

The images or other third party material in this chapter are included in the chapter's Creative Commons licence, unless indicated otherwise in a credit line to the material. If material is not included in the chapter's Creative Commons licence and your intended use is not permitted by statutory regulation or exceeds the permitted use, you will need to obtain permission directly from the copyright holder.

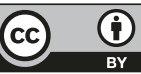

